\title{
Investigating Social Capital Impact on the Pro-Environmental Behavior of Rural People in Marivan Township
}

\author{
Ali Shams and Himan Yazdani \\ Department of Agricultural Extension, Communication and Rural Development, Faculty of Agriculture, \\ University of Zanjan, Iran \\ Agricultural Extension and Education, Faculty of Agriculture, University of Zanjan, Iran
}

\begin{abstract}
Every individual and social behavior of people affect the environment and its problems. This descriptive correlation study aimed to investigate the impact of social capital on the pro-environmental behavior of rural people. All of the rural households in Marivan Township $(N=11228)$ consist the target population which Cochrane sampling formula, 250 subjects selected through randomized multi-stage sampling method. Date analyzed using Spss 21 software and correlation and regression statistical methods. The results showed that 82.8 percent of people behave moderately with the environment. The level of social trust, social cohesion and social participation in the viewpoint of the majority of people (65.6, 62.4 and 98 percent respectively) were moderate. There was a positive and meaningful correlation among three components of social capital with pro-environment of rural people. Multiple regression analysis revealed that four variables of educational level, social participation, age and social cohesion explained 37.7 percent of rural people pro-environmentally behavior.
\end{abstract}

Keywords: Marivan Township, Pro-environmental Behavior, Rural Area, Social Capital.

\section{Introduction}

Environment and natural resource conservation are one of the most important challenges of all countries in the twenty-first century. Ignoring the abovementioned fact will affect negatively on human health and result in bad consequences economically and socially. One of the things that seriously threaten the environment is people destructive behavior regarding the environment. Every individual and social behavior of people affect the environment and creates some problems. It is important to persuade people to behave friendly with the environment. The importance of social capital for local development in rural districts has been the subject of a growing number of studies in recent years. Social capital refers to the features of social organization, such as trust, norms, and networks that can improve the efficiency of society by facilitating coordinated action. Social capital is the ability to improve cooperation between residents of society and coordination in the development process. In order to guarantee mutual benefits for the environment and residents, it has particular importance for the local-level collective management of common resources, such as the environment. Environmentally responsible behavior is a key element in sustainable development in developing countries. One way to avoid damaging the environment is changing human behavior. The connection between the environment and social capital is one of the new topics that researchers have taken into consideration [1]- [4]. Most studies emphasize that social capital affects environmental behavior, and both influence the implementation of environmental policies [1], [6]. Vaghefi, and Haghighatian (2014) [7], concluded in their research that social capital had a direct relation with and facilitating environmental pro-environmental behaviors. Gorgi garsami et al. (2013) [8], showed that there is a significant relationship between the important indices of social capital (participation, cohesion and trust) and environmental management of individuals. Liu et al (2014) [5], emphasize that environmental factors can be affected by strengthening the components of social capital and, in particular, trust. Surjono et al (2015) [9], conclude that social capital must be strengthened to achieve rural development, in order to reduce environmental degradation. Azucena et al (2013) [10], showed that many factors affect on protecting the environment and social capital is one of them. Cascante et al. (2015) [11], found that social capital is one of the factors influencing the environmental behavior of people in the community, and can contribute to positive behaviors toward the environment. Larson et al (2015) [12], examined the factors influencing environmental 
behavior and concluded that social capital, and especially the components of participation, trust, and cohesion, have a significant impact on environmental behaviors. Marivan Township in the west of Iran with rich natural views like Zarivar Lake and other Jungles attract very tourists all around the country. So, this study has done to answer questions e.g. what is the status of social capital in the rural areas? What are the pro-environment behaviors of the rural household? Are social capital affect the behavior of rural people regarding the environment.

\section{Methodology}

The purpose of this descriptive-correlational study was to investigate the social capital of villages and the effect of social capital on the pro-environment behavior of rural people in Marivan Township. The research tool was a researcher made questionnaire which its content and face validity verified by an expert panel in this field. The questionnaire had three sections: in section one, demographic questions asked, in section two social capital of rural people were assessed based on the composite index with 24 items and respondent were asked to answer on 5 Responses (very low $=1$ to very high=5). In section three of the questionnaire, rural men were asked to answer questions regarding their behavior about every environment issues. The target population consisted all rural households in Marivan Township ( $\mathrm{N}=11228)$ which 250 of them as the sample were selected based on Cochran sampling formula and multi-stage randomized sampling method. A pilot study with 30 rural people was done and needed correction in every question and whole questionnaire were done. Data were analyzed with SPSS/Win 20 software and statistics of frequency distribution, average, standard deviation, correlation coefficient, and multiple regressions were used for reporting the analysis.

\section{Result and Discussion}

The results of showed that the majority of respondents (59 percent) were in the range of 35 to 50 years old. 95.6 percent of respondents were married. In terms of education level, 21.2 percent were illiterate, 9.2 percent in reading and writing level, 38.8 percent of primary school degree, 14.4 percent of guidance school, 11.2 percent of diploma, 5.2 percent of undergraduate education level or above. The results showed that 82.8 percent of people behave moderately with the environment. The level of social trust, social cohesion and social participation in the viewpoint of the majority of people (65.6, 62.4 and 98 percent respectively) were moderate. There was a positive and meaningful correlation among three components of social capital with pro-environment of rural people and by increasing social capital, responsible environmental behaviors also would be increased. The results of researches such as Vaghefi and Haghighatian (2014) [7], Gorgi garsami et al. (2013) [8], Baghaie et al. (2008), [13], Liu et al (2014) [5], Surjono et al (2015) [9], Cascante et al (2015) [11], showed that social capital and its components have a positive and direct effect on environmental behaviors, which is consistent with the results of the present study. Multiple regression analysis revealed that four variables of educational level, social participation, age and social cohesion explained 37.7 percent of rural people pro-environmentally behavior.

\section{References}

[1] N. Jones, "Environmental activation of citizens in the context of policy agenda formation and the influence of social capital”. The Social Science Journal., vol.47, Pp. 121-136, 2010.

https://doi.org/10.1016/j.soscij.2009.05.008

[2] H. Ishihara, and P. Unai, "Social capital in community level environmental governance: A critique". Journal of Ecological economic., vol. 68, Pp. 1549 - 156 2, 2009

[3] J. Price, and Z. Leviston, "Predicting pro-environmental agricultural practices: The social, psychological and contextual influences on land management". Journal of Rural Studies., vol. 34, Pp. 65-78, 2014

https://doi.org/10.1016/j.jrurstud.2013.10.001 
[4] S. Salehi, and L. Emamgholi. The effect of social capital on environmental behavior (Case Study: province of Kurdistan), Iranian Journal of Sociology (Isa)., vol.13, no.4, Pp. 90-115, 2012

[5] J. Liu, H. Qu, D. Huang, G. Chen, X. Yue, X. Zhao, and Zh. Liang, "The role of social capital in encouraging residents" pro-environmental. behaviors in community-based ecotourism". Journal of Tourism Management., vol. 41, Pp.90-201,2014

https://doi.org/10.1016/j.tourman.2013.08.016

[6] M. Aghili, GH. Khoshfar, and S. Salehi, "Social capital and environmental responsible behaviors in northern Iran (Case study: Gilan, Mazandaran and Golestan)", Journal of Agricultural Sciences and Natural Resources., vol. 16, no.1, Pp.236-251, 2009.

[7] E. Vaghefi, and M. Haghighatian The Impact of Cultural Capital (Institutional Dimension) on Socio-Environmental Behaviors with the Sustainable Urban Development Approach (The Case of Shiraz City), Journal of urban economics and management., vol. 2, no. 8, Pp:48-65, 2014.

[8] A. Gorgi garsami, H. Radneya, R. Safari, A. Asadi rad "Investigate the relationship between social capital and citizen participation in environmental management and urban health", The first conference of national and urban and environmental services, Mashhad, Iran, 2013.

[9] P. Surjono, and F. Sutikno "Gender Equality and Social Capital as Rural Development Indicators in Indonesia (Case: Malang Regency, Indonesia)”. Journal of Procedia - Social and Behavioral Sciences, 2015, Vol.211, Pp. 370-374.

[10] M. Azucena, V. Molina, A. Fernandez, and I. Olaizola, "Environmental knowledge and other variables affecting proenvironmental behavior: comparison of university students from emerging and advanced countries. Journal of Cleaner Production., vol. 61, Pp.130-138, 2014.

[11] D. Cascante, A. Harper, and G. Sticks, "International amenity migration: Examining environmental behaviors and influences of amenity migrants and local residents in a rural community". Journal of Rural Studies., vol. 38, Pp.1-11, 2015

https://doi.org/10.1016/j.jrurstud.2015.01.005

[12] L. Larson, Stedman, R., Cooper, C and Decker, D "Understanding the multi-dimensional structure of proenvironmental behavior". Journal of Environmental Psychology., vol. 43, Pp.112-124, 2015. https://doi.org/10.1016/j.jenvp.2015.06.004

[13] M. Baghaie. M. Chizari, GH. Pezeshkirad, and S. Feli, "Individual and social factors affecting rural participation in watershed management of Hunejan Zarcheshmeh area", Iranian Agricultural Extension and Education Journal., vol. 4, no.1, PP.73-87, 2008. 